\title{
BAMBOONOMIC:
}

\section{EKONOMI BAMBU PENDUKUNG DESA WISATA TEGAREN}

\author{
Jojok Dwiridhotjahjono \\ UPN “Veteran" Jawa Timur \\ Email: jojokdwiri@gmail.com \\ Prihandono Wibowo \\ UPN “Veteran" Jawa Timur \\ Email: prihandono_wibowo@yahoo.com \\ Praja Firdaus Nuryananda \\ UPN “Veteran" Jawa Timur \\ Email: firdaus.praja@gmail.com
}

\begin{abstract}
Tegaren village is the biggest besek producer in Trenggalek, East Java. In collaboration with UPN "Veteran" of East Java, the people of Tegaren then developed an educational tourism that made besek as the main tourist attraction. Using the asset based community development (ABCD) method, leadership, and tourist gaze 3.0, the research team sought to make a scientific contribution to the development of the Tegaren's tourism. After proceeding for one year, Tegaren's people, especially women who made besek, began to feel the impact of improving the quality of life by the existence of a tourism village. There are three scientific arguments why besek, or bamboo, is used as the backbone of the development of the Tegaren's tourism and later we call it as bamboonomic, namely 1) bamboo and besek have long been one of the heart of Tegaren's life, 2) the tourism which was built based on natural assets and cultural assets creates ways of feeling as conceived in tourist gaze 3.0, and 3) this tourism is able to bring up and come up with leadership that brings Tegaren more advanced and prosperous.
\end{abstract}

Keywords: besek, asset based community development, tourism, village, bamboo 


\section{Pendahuluan}

Pemerintahan Presiden Joko Widodo memiliki prioritas untuk membangun wilayah pedesaan di Indonesia. Hal ini tertuang dalam visi Nawacita yang diusung Joko Widodo sejak 2014. Visi ini berisi program pembangunan Presiden Joko Widodo selama 5 tahun, dari 2014-2019. Pembangunan desa masuk dalam prioritas Nawacita nomor tiga yang berbunyi "Membangun Indonesia dari Pinggiran dengan Memperkuat Daerah-Daerah dan Desa dalam Kerangka Negara Kesatuan." Visi ini selaras dengan UU no 6 tahun 2014 yang mengamanatkan pemerintah untuk memajukan wilayah pedesaan dan meningkatkan taraf hidup dan kesejateraan masyarakat di pedesaan.

Selaras dengan undang-undang dan visi pembangunan pemerintah, Program Studi Hubungan Internasional UPN "Veteran " menjalin kerjasama dengan Desa Tegaren, Trenggalek, untuk berkolaborasi bersama masyarakat Desa Tegaren dalam pengembangan desa tersebut. Hal ini juga selaras dengan Nota Kesepahaman (Memorandum of Understanding (MoU)) antara UPN “Veteran" Jawa Timur dengan Kabupaten Trenggalek (UPN, 2017) dan visi baru program studi HI UPN “Veteran" Jawa Timur yang mengusung karakter kajian local to global. Salah satu fokus Program Studi HI UPN “Veteran" Jawa Timur adalah mengkaji "pariwisata internasional dan ekonomi kreatif". Kajian ini memfokuskan pada bagaimana Program Studi HI UPN "Veteran" Jawa Timur dapat berkontribusi pada pengembangan potensi wisata lokal agar dapat dikenal dalam skala nasional, regional, dan internasional. Sebagaimana dijelaskan oleh Sudarmayasa dan Lanang Nala (2019) bahwa pariwisata bisa menjadi konsep yang memberikan andil kepada peningkatan kesejahteraan rakyat kecil di pedesaan. Di sisi lain, Desa Tegaren menginisiasi kontribusi bersama dengan akademisi Program Studi HI UPN "Veteran" Jawa Timur untuk menyusun roadmap pembangunan Desa Tegaren sebagai desa wisata. Karena itu, kerjasama antara Program Studi HI UPN “Veteran” 
Jatim dan Desa Tegaren adalah milestone realisasi kolaborasi antara pemerintah, akademisi, dan masyarakat.

Target kolaborasi antara Program Studi Hubungan Internasional UPN “Veteran" Jawa Timur dan Desa Tegaren adalah pengembangan Desa Tegaren sebagai desa wisata. Kolaborasi ini dimulai sejak 2018 ketika pihak desa berinisiatif bekerjasama dengan Program Studi HI UPN “Veteran" Jawa Timur untuk pengembangan Embung Banyu Lumut di Desa Tegaren. Sebelumnya pada 2016 pihak desa memproyeksikan embung tersebut untuk menjadi obyek wisata. Desa berinisiatif untuk memaksimalkan fungsi embung yang sebelumnya hanya berfunsgis sebagai tempat penampungan air.

Sebagai langkah awal pengembangan desa wisata, pada 2018 Program Studi HI UPN “Veteran” Jawa Timur menginisiasi penandatanganan MoU antara dengan Program Studi, pemerintah Desa Tegaren, dan Lembaga Masyarakat Desa Hutan (LMDH) mengenai pengembangan Embung Banyu Lumut. MoU ini ditindaklanjuti dengan pengerahan dosen dan mahasiswa secara bertahap untuk kepentingan penelitian lapangan dan pengabdian masyarakat. Penelitian lapangan dan pengabdian masyarakat tim dosen dan mahasiswa dilakukan untuk memetakan potensi dan keunggulan yang dimiliki masyarakat desa dan alam sekitar embung. Dialog berkesinambungan juga dilakukan antara Program Studi HI UPN Jatim dan pihak pemangku kepentingan di desa untuk mengawal realisasi masterplan pengembangan Embung Banyu Lumut. Sejak 2018, pihak desa dan masyarakat bergotong royong mengembangkan sarana awal Embung Banyu Lumut, seperti pembuatan rumah pohon, pengecatan, pembuatan spot foto, dan pembuatan jalan setapak ke gua di sekitar embung. Terdapat tempat yang dialokasikan bagi masyarakat Desa Tegaren untuk berjualan di sekitar embung. Dalam hal ini, pihak desa dan Program Studi berkomunikasi secara berkesinambungan. 


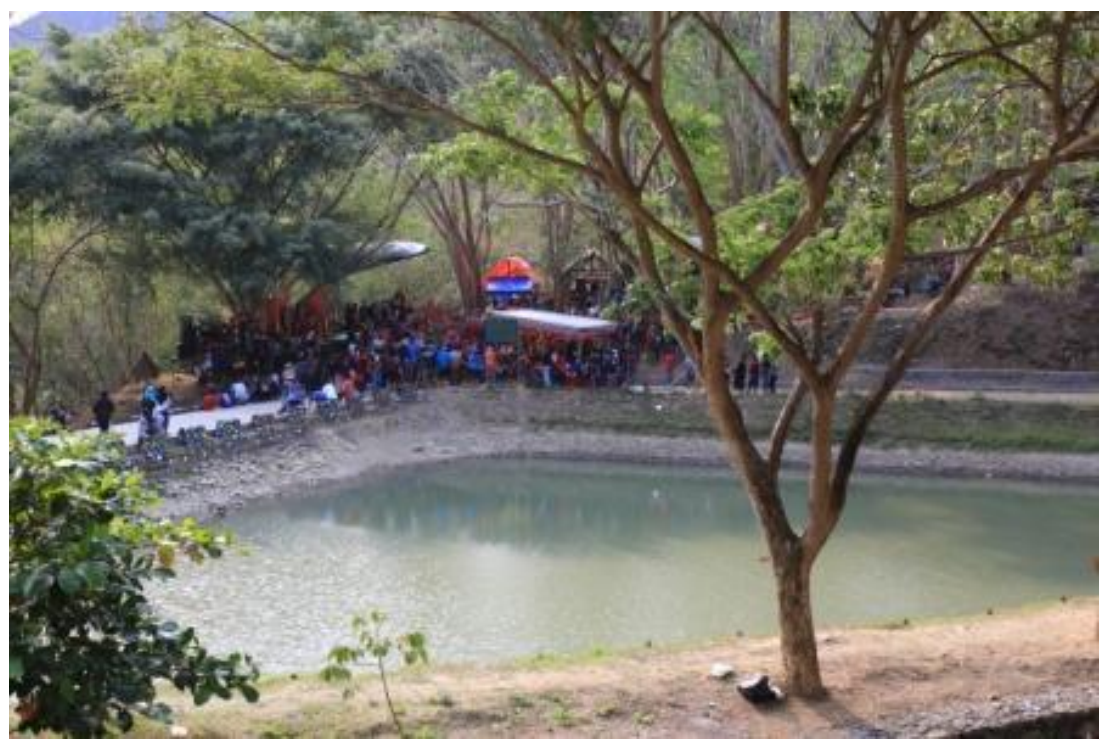

Gambar 1. Embung Banyu Lumut di Desa Tegaren, Trenggalek yang sedang dikembangkan untuk menjadi destinasi wisata daerah.

Sumber: Dokumentasi peneliti (2018)

Dari hasil komunikasi, didapatkan perkembangan bahwa Embung Banyu Lumut telah mulai dikenal di kawasan Trenggalek. Diantaranya, Embung Banyu Lumut mendapat kunjungan Wakil Bupati Trenggalek, menjadi tempat event sosialisasi anti Narkoba oleh BNN Trenggalek (CGaS, 2018), kerja bakti dan kunjungan Muspika kecamatan Tugu, Trenggalek. Selain itu, masyarakat dari kecamatan lain, seperti dari kecamatan Durenan yang berbatasan dengan Tulungagung, mulai mengenal Embung Banyu Lumut sebagai objek wisata. Pengembangan embung masih dalam tahap awal sehingga masih terus memerlukan pengembangan.

Pada 2019, kerjasama antara Program Studi HI UPN Veteran Jawa Timur dan Desa Tegaren dikembangkan melalui program "Pemberdayaan Perempuan Lokal Melalui Kerajinan Bambu Untuk Pembangunan Kapasitas Ekonomi Desa Tegaren, Trenggalek". Program ini masuk dalam skema Program Kemitraan Masyarakat (PKM) yang didanai oleh Kemristekdikti. Kegiatan ini berfokus pada pemberdayaan perempuan lokal Desa Tegaren melalui pengembangan hasil olahan produk kerajinan bambu. Bambu merupakan aset potensial yang dimiliki oleh Desa Tegaren. 
Namun pemanfaatan bambu dirasa belum maksimal karena hasil produk olahannya hanya berupa satu produk, yaitu besek. Diharapkan program kemitraan ini dapat berkontribusi pada peningkatan nilai tambah dan diversifikasi hasil olahan bambu. Dengan demikian produk kerajinan bambu dapat menjadi salah satu sumber meningkatkan kapasitas ekonomi desa sekaligus menaikkan tingkat kesejahteraan keluarga di Desa Tegaren.

Program kemitraan ini dilaksanakan melalui dua metode, yaitu pendampingan terpadu dan musyawarah desa. Pendampingan terpadu dilaksanakan baik dalam tataran konseptual maupun aplikasi di lapangan. Pendampingan dilakukan dengan mendampingi masyarakat desa untuk mengembangkan produk hasil olahan bambu. Kegiatan pendampingan dilakukan mulai dari perencanaan, pelatihan, produksi, sampai dengan pemasaran. Kedua, dalam program ini, tim Program Studi HI melibatkan musyawarah desa untuk memantau perkembangan program. Meski dilaksanakan secara informal, namun masyarakat desa dapat memberikan masukan dan tukar pikiran dengan tim Program Studi HI. Sebagai realisasinya, tim Program Studi mendampingi masyarakat Desa Tegaren untuk melakukan studi banding ke Desa Wonoanti yang terkenal sebagai sentra penghasil kerajinanan bambu di Trenggalek. Dari studi banding tersebut, dicapai kesepakatan antara Desa Wonoanti dan Desa Tegaren untuk meningkatkan kemampuan pengolahan hasil produk bambu Desa Tegaren. Kesepakatan tersebut berupa persetujuan Desa Wonoanti untuk menerima 2-3 remaja Desa Tegaren untuk magang di sentra bambu Desa Wonoanti. Selain itu, Desa Wonoanti menyanggupi untuk melibatkan pengrajin Desa Tegaren dalam pesanan besek dan pincuk. Selain itu, tim Program Studi HI juga membantu mempromosikan hasil produk besek Desa Tegaren ke relasi Program Studi HI UPN “Veteran" Jawa Timur di kota Batu dan Surabaya. Perkembangan di sektor ini masih pada tahap awal sehingga memerlukan sinergisitas lebih lanjut antara Program 
Studi HI UPN “Veteran” Jawa Timur, pemerintah Desa Tegaren, dan pengrajin bambu di desa tersebut.

Dari sektor embung dan bambu di Desa Tegaren, diidentifikasikan permasalahan awal yang dihadapi Desa Tegaren. Pertama, kesadaran dan kemampuan sumber daya manusia yang ada di Desa Tegaren masih belum memadai untuk pengembangan desa wisata Tegaren. Kedua, kontur sosial budaya warga Tegaren yang acuh tak acuh terhadap pengembangan desa mereka, terutama jika tidak ada dorongan dari pemerintah desa. Ketiga, rata-rata pendapatan warga Desa Tegaren masih belum menentu, sebab kebanyakan dari warga bermata pencaharian petani, yang bergantung kepada cuaca dan dinamika harga komoditas di pasar. Keempat, letak geografis Desa Tegaren yang jauh dari pusat kota dan terkategori sebagai "desa pinggiran” yang berbatasan langsung dengan Kabupaten Ponorogo.

Solusi yang ditawarkan oleh Program Studi HI UPN “Veteran” Jawa Timur untuk mengembangkan Desa Tegaren sebagai desa wisata adalah menggunakan pendekatan "Pengembangan Komunitas Berbasis Aset" (Asset Based Community Development/ABCD). Artinya, dalam pendekatan ini, tim Program Studi HI tidak memusatkan fokusnya untuk memperbaiki masalah dan kekurangan yang dihadapi oleh Desa Tegaren. Sebaliknya, tim Program Studi HI berfokus pada bagaimana masyarakat desa secara mandiri dan komunal, dapat mengembangkan aset-aset potensial dan objek unggulan yang dimiliki desa tersebut. Tim Program Studi HI tidak menciptakan struktur ketergantungan terhadap invervensi luar. Sebaliknya, dengan metode ABCD, tim Program Studi HI mencoba membangkitkan kesadaran komunitas masyarakat desa, sehingga transformasi berkelanjutan dilaksanakan oleh masyarat desa itu sendiri secara mandiri. Karena itu, dalam setiap perencanaan dan implementasi program, selalu dilibatkan unsur masyarakat, karang taruna, aparat pemerintahan desa, dan BPD. 


\section{Kerangka Pikir}

\section{Pengembangan Komunitas dengan Metode ABCD}

Konsep kunci pembangunan desa adalah mempersiapkan infrastruktur sosial dan infrastruktur fisik desa. Infrastuktrur fisik beroreintasi jangka pendek, dengan pembangunan sarana dan prasarana fisik. Sedangkan pembangunan infrastruktur sosial berorientasi jangka panjang, Infrastruktur sosial melingkupi pemanfaatan aset potensial milik desa serta keterlibatan aktif masyarakat dalam memaksimalkan potensi desa. Kerjasama antara pemerintah, aparatur desa, dan masyarakat desa memungkinkan pembangunan berkelanjutan. Dalam hal ini, masyarakat desa berperan sebagai subyek pembangunan, bukan lagi sebagai obyek pembangunan sebagaimana masa sebelumnya. Masyarakat juga dilibatkan dalam pengawasan program pembangunan desa. Desa diharapkan dapat "menggali" potensi sumber daya dan aset unggulan yang dapat dikelola secara mandiri. Kesejahteraan, berdaya saing, pembangunan keberlanjutan, dan keselarasan lingkungan adalah tujuan terkini dari pembangunan desa.

Metode Asset Based Community Development (ABCD) relevan terhadap konsep kunci tersebut. Metode $\mathrm{ABCD}$ berorientasi pada bagaimana individu dan seluruh komunitas berkontribusi pada pengembangan mereka sendiri dengan cara: menggali dan memobilisasi kapasitas dan aset desa, memodifikasi dan memperbaiki struktur yang ada, mengartikulasikan dan memvisualisasikan "mimpi" perubahan. Metode $\mathrm{ABCD}$ dilakukan dengan menggali cerita sukses di masa lampau, kisah sukses masa kini, dan peluang cerah di masa depan. Tiga elemen tersebut digunakan secara stimultan untuk membangkitkan energi positif dan inspirasi bagi komunitas (Russel, 2016). Selain itu, dalam metode ini, dilakukan pemetaan aset yang tersedia, memfokuskan analisis kekuatan dan aset yang ada saat ini, menetapkan tujuan dan visi bersama yang inspiratif, membuat rancangan perubahan yang transformatif dan terbuka, menciptakan kompetensi seluruh 
anggota komunitas, serta memberdayakan seluruh anggota komunitas untuk upaya pengembangan komunitas (Dureau, 2013).
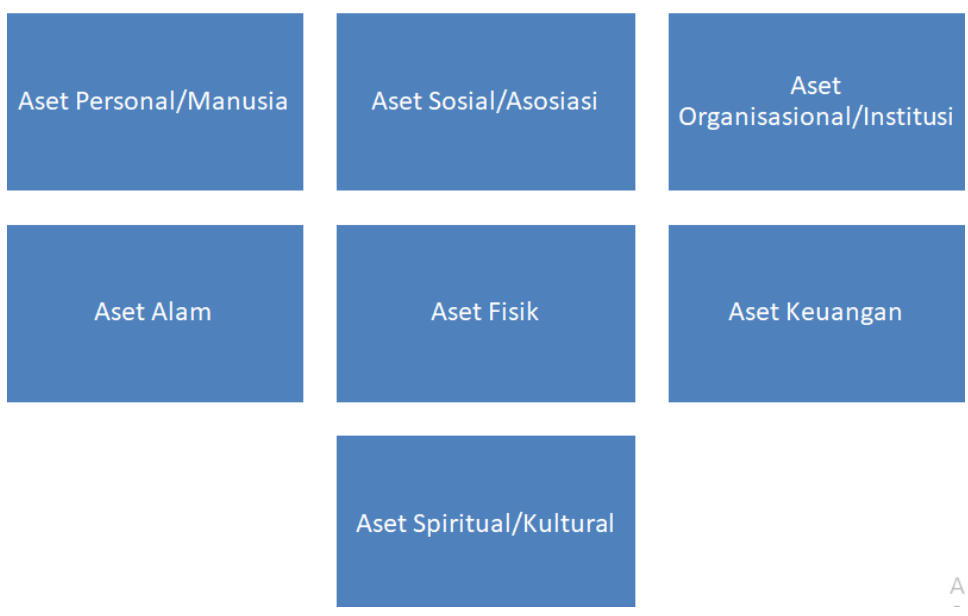

Gambar 2. Klasifikasi aset dalam metode ABCD.

Sumber: Olahan data peneliti (2018)

Pengembangan komunitas berbasis aset bertumpu pada apa yang sudah ada dalam komunitas tersebut. Metode ABCD menekankan cara berpikir kreatif dan imajinatif untuk mencapai peluang baru dari dalam komunitas (McKnight dan Kretzmann, 1993). Orientasi ini dapat mengubah apa yang manpaknya sekarang menjadi masalah menjadi kemungkinan-kemungkinan dengan prospek cerah di masa depan. Selain itu, metode ABCD memungkinkan inklusi sosial dan gender dalam pengembangan komunitas. Asumsinya, setiap orang memiliki potensi, bakat, kompetensi, dan peran masing-masing untuk pengembangan komunitas. Keterlibatan perempuan dan distabilitas-yang selama ini terpinggirkan-misalnya, memliki kesempatan sama untuk berkontribusi dalam komunitas (Dureau, 2013). Metode ini memiliki banyak kesamaan dengan konsep pembangunan pariwisata berkelanjutan oleh McIntyre (dalam Agfianto dkk, 2019). 
Dalam metode ini, intervensi yang dilakukan pemerintah maupun organisasi donor luar, hanya berfungsi sebagai menciptakan pra-kondisi agar sebuah komunitas dapat menemukan kapasitasnya sendiri untuk berkembang. Fasilitasi dilakukan untuk mendorong anggota komunitas untuk menyadari dan mempelajari potensi aset dan sumber daya yang mereka miliki. Untuk selanjutnya, komunitas dapat mengembangkan potensi aset secara mandiri dan berkelanjutan (Dureau, 2013). Ketergantungan dari pihak organisasi donor luar adalah konsep yang paling dihindari dalam metode ABCD.

\section{Kepemimpinan dalam Metode ABCD}

Kepemimpinan merupakan hal vital dalam pembangunan desa. Hal ini karena kepemimpinan dapat menentukan arah pembangunan, eksekusi perencanaan pembangunan, serta evaluasinya (Ganz, 2010). Namun terdapat perbedaan signfikan antara gaya kepemimpinan dalam metode ABCD dengan gaya kepemimpinan tradisional. Dalam kepemimipinan tradisional, kepemimpinan cenderung dipegang terpusat oleh elit serta bergaya feodal. Dimana dalam kepemimpinan tradisional, warga harus menerima dengan puas dengan apa yang diberikan oleh pemerintah. Dalam hal ini, warga hanya dijadikan obyek pembangunan. Namun dalam pendekatan yang baru, kepemimpinan bersifat desentralisasi. Kepemimpinan yang terdesentralisasi bukan berarti menghilangkan kepemimpinan lama, tetapi memunculkan menyebar kepemimpinan ke dalam sektor yang berbeda-beda (Goleman, 1998). Dengan demikian, tercipta pusat-pusat kepemimpinan baru yang memungkinkan check $\mathcal{E}$ balances. Selain itu, desentralisasi kekuasaan dapat memperluas keterlibatan partispasi aktif masyarakat desa dalam pembangunan desanya. Dapat muncul ide-ide baru yang dapat disampaikan oleh anggota komunitas. 
Desentralisasi kepemimpinan menuntut adanya forum pertemuan multipihak. Asumsinya, visi bersama komunitas dipunggawangi oleh seluruh elemen komunitas (Conger, 1991). Seluruh komunitas memiliki peran yang relevan dan kapabilitas masing-masing untuk mewujudkan visi bersama. Karena itu, diperlukan persetujuan kolektif dan kolaborasi bersama. Dengan ini, terdapat kombinasi pendekatan bawah ke atas dan atas ke bawah (Dureau 2013). Dalam konteks pembangunan desa, kehadiran Negara yang telalu kuat dapat mematikan prakarsa lokal desa untuk membangun desa berdasar potensinya sendiri. Karena itu, perlu diciptakan emansipasi lokal dalam pembangunan dan pengembangan masyarakat desa. Dengan kata lain, telah terjadi transformasi paradigma, dari "membangun desa" kepada "desa membangun". Konsep "desa membangun" membutuhkan partisipasi masyarakat desa secara keseluruhan.

\section{Tourist Gaze 3.0}

Perkembangan pariwisata (tourism) dicatat oleh John Urry dan Jonas Larsen dalam tiga tahap. Ketiga tahap ini mencerminkan perkembangan pariwisata secara konseptual/ide/gagasan. Konsep pertama akan pariwisata oleh John Urry dan Jonas Larsen adalah tourist gaze atau tourist gaze 1.0. Konsep tersebut kemudian dikembangkan mengikuti perkembangan zaman dan fenomena-fenomena yang terjadi di sekitar pariwisata menjadi tourist gaze 2.0 dan tourist gaze 3.0.

Pada tahun 1990, John Urry menelurkan konsep tourist gaze. Konsep ini terinspirasi dari gagasan Michael Foucault tentang medical gaze. Secara padat dan singkat, tourist gaze adalah konsepsi Urry tentang pariwisata yang berpusat dan berangkat dari visualisasi pariwisata (Urry, 1990). Visualisasi pariwisata disini bisa didefinisikan secara luas, seperti pandangan turis akan destinasi, ekspektasi turis akan destinasi, imajinasi turis akan sebuah destinasi pariwisata, dan pada tingkat tertentu tourist gaze dimaknai sebagai ways of seeing. Maka, berangkat dari tourist gaze 1.0 ini, pariwisata kemudian menjadi aktifitas ekonomi yang sangat "memanjakan" 
secara visual (Larsen, 2014). Semua perencanaan maupun pembangunan destinasi pariwisata hanya berfokus pada kemasan visual destinasi pariwisata tersebut. Visualisasi tersebut bisa dicontohkan seperti hiasan yang memperindah destinasi wisata, lighting, sampai bangunan-bangunan artifisial yang dibangun untuk memperindah destinasi wisata. Tidak heran pula, wacana pariwisata di periode 1990-an adalah wacana tentang visual. Maka jika kita perhatikan, pariwisata periode tersebut merupakan periode emas destinasi wisata alam, seperti pantai, gunung, dan laut.

Pada awal periode 2000-an, tepatnya pada tahun 2002, Urry dan Larsen mengembangkan konsep tourist gaze 2.0. Konsep ini merupakan pengembangan dari tourist gaze 1.0. Pengembangan konsep ini beranjak dari fenomena global, yakni semakin menanjaknya tingkat mobilitas manusia secara drastis dalam skala global. Peningkatan mobilitas manusia ini, menurut Urry dan Larsen, juga ikut mempengaruhi pariwisata secara global. Muncul kemudian asumsi bahwa semakin tinggi mobilitas manusia secara global, maka ada peningkatan jumlah turis yang datang ke destinasi wisata. Kedatangan turis ke destinasi wisata tersebut bisa saja sekali, namun bisa juga berkali-kali. Pariwisata kemudian tidak hanya dibentuk melalui ways of seeing, tapi juga corporeal movements, atau pergerakan fisik (Larsen, 2014).

Ada beberapa konsekuensi konseptual, menurut Urry dan Larsen, yang berubah ketika tourist gaze 1.0 menjadi tourist gaze 2.0. Corporeal movement membuat tourist gaze 1.0 yang mengandalkan wisata visual juga harus ikut bisa menyediakan space (ruang) untuk pergerakan turis. Maka pada periode ini kita bisa melihat ruangruang kecil yang terdapat di daerah urban, yang kemudian dikemas dengan seni visual yang menarik, dapat menjadi sebuah destinasi wisata yang menarik pula (Larsen, 2014). Metode ini kemudian yang dipakai oleh banyak café atau kedai minuman untuk menarik pengunjung. 
Tourist gaze 3.0, oleh sebabnya, adalah pengembangan dari tourist gaze 1.0 (ways of seeing) dan tourist gaze 2.0 (ways of moving). Pengembangan tourist gaze 3.0 ini lalu menekankan relasi antara ways of seeing dan ways of moving (Larsen, 2014). Urry dan Larsen kemudian menyadari bahwa pariwisata sebenarnya tidak hanya pencitraan visual ataupun pergerakan fisik, namun juga relasi sosial diantara keduanya pula. Maka, tourist gaze 3.0 adalah ways of feeling. Fase ketiga ini lebih menekankan bahwa pariwisata adalah perkara sebuah destinasi wisata membuat turis-turis yang datang disitu merasakan enkapsulasi suasana. Maka pariwisata kemudian tidak hanya perkara menyediakan pemandangan dan perencanaan tata ruang yang luas, namun juga bagaimana membuat kondisi dan suasana yang sesuai dengan konsep yang diinginkan sehingga para turis merasa "atmosfir" yang sangat privat ketika mereka berada di destinasi wisata. 


\section{Pembahasan}

\section{Bambu sebagai Kunci Utama Penggerak Desa}

Hampir 100\% dari penduduk perempuan Desa Tegaren bermatapencaharian sebagai pengrajin besek ${ }^{1}$. Desa Tegaren sendiri adalah daerah di Kabupaten Trenggalek dengan produksi besek paling tinggi/besar se-wilayah kabupaten. Bagi para penduduk perempuan di Desa Tegaren, kerajinan besek atau keterampilan membesek merupakan warisan budaya lokal yang diturunkan lintas generasi. Dulunya Desa Tegaren merupakan produsen terbesar besek dengan jumlah pengrajin yang lebih banyak daripada sekarang. Bahkan, menurut Nurngaini salah satu pengepul besek, harga 1 kodi besek bisa mencapai hanya Rp. 5.000,-. Harga tersebut menandakan bahwa penawaran besek yang sangat tinggi sekali. Sekarang harga besek per kodi mencapari Rp. 17.000,- sampai Rp. 20.000,-. Hal ini menandakan semakin menurunnya penawaran, namun permintaan besek masih tetap tinggi.

Besek sendiri berbahan baku bambu. Bambu yang dibeli atau diambil oleh pengrajin pada awalnya berupa batangan. Batangan bambu tersebut kemudian dipotong tipis untuk kemudian dianyam menjadi besek. Uniknya, selain sebagai matapencaharian para penduduk perempuan di Desa Tegaren, mbesek seringkali dilakukan para penduduk perempuan disela-sela waktu. Maka, jika Anda berkunjung ke Desa Tegaren, aktifitas membuat besek tidak mengenal waktu, bisa dilakukan di pagi hari, siang hari, maupun sore hari. Walau banyak yang menjadikan kegiatan membuat besek sebagai mata pencaharian utama, namun tidak sedikit pula penduduk perempuan yang menjadikan aktifitas mbesek sebagai aktifitas sampingan.

\footnotetext{
${ }^{1}$ Besek adalah tempat/bungkus makanan/sajian yang terbuat dari anyaman bambu. Besek biasa digunakan untuk bungkus keripik tempe, tape, tahu, atau makanan lainnya. Bambu sebagai bahan baku pembuatan besek didapat dengan memesan kepada para penjual bambu batangan dari Desa Tegaren, ataupun dari daerah lain. Pun para pengrajin besek masing-masing memiliki lahan yang luas dibelakang dengan rimbunan bambu yang sangat banyak. Oleh karena itu, bambu adalah salah satu kunci dalam penggerakan ekonomi Desa Tegaren.
} 


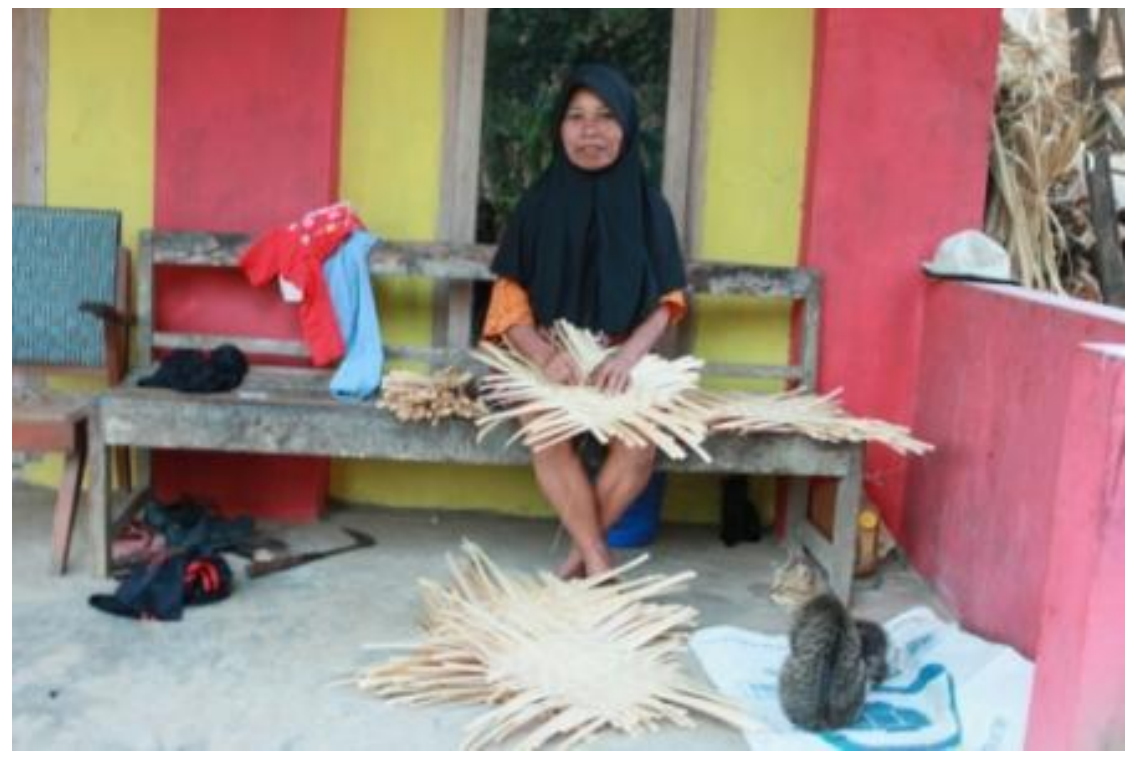

Gambar 3. Salah seorang pengrajin besek di Desa Tegaren.

Sumber: Dokumentasi peneliti (2018)

Ada sekurang-kurangnya tiga argumentasi utama mengapa bambu menjadi kunci dalam penggerak ekonomi Desa Tegaren. Pertama, bambu adalah nilai lokal masyarakat Desa Tegaren. Hampir semua pengrajin bambu atau pembuat besek di Desa Tegaren memiliki lahan di belakang rumah mereka yang tertanam banyak sekali bambu disana. Maka, dalam proses pembuatan besek, bambu yang didapatkan oleh para pengrajin diambil dari lahan belakang rumah mereka selain mereka membeli dari daerah lain melalui pengepul bambu. Kedua, kerajinan besek sudah dilakukan oleh warga Tegaren sejak dulu, dan bambu selalu hadir dan tersedia. Artinya, mulai sejak dulu, ekonomi bambu ini sudah berputar. Argumentasi kedua, oleh sebabnya, adalah ketersediaan bambu yang melimpah, khususnya di Trenggalek, dan bambu adalah sumber daya alam yang bisa diperbaharui (renewable resources). Sedangkan argumentasi ketiga adalah ekonomi bambu (bamboonomic) ini sudah menyatu dengan banyak aspek kehidupan masyarakat Tegaren. Selain pengrajin, beberapa penduduk di Desa Tegaren juga menjadi pengepul besek. Besekbesek tersebut kemudian dijual di pasar atau tempat oleh-oleh. Selain pengepul, penduduk Desa Tegaren juga menjadi penyedia bambu yang digunakan bahan baku besek. Jika ditarik benang merah, ekonomi bambu di Desa Tegaren sudah dikerjakan 
mulai dari hulu sampai hilir. Oleh karena itu, ekonomi bambu merupakan kategori aset dalam metode $\mathrm{ABCD}$ (asset based community development), atau dalam bahasa Cornac Russel, ekonomi bambu di Desa Tegaren merupakan "the strong" daripada "the wrong".

Tim peneliti pun telah membantu gerak ekonomi bambu di Desa Tegaren. Salah satu usaha yang dilakukan untuk membantu ekonomi bambu ini adalah dengan cara meningkatkan permintaan akan besek. Hal ini dilakukan pada saat perayaan Hari Raya Kurban 2019 yang lalu. Menyambut adanya gerakan nasional untuk mengganti kantong plastik yang biasanya digunakan untuk membungkus daging kurban dengan tempat lain, tim peneliti menginisiasi gerakan Besek Untuk Kurban (Beban). Kegiatan ini bertujuan untuk menambah permintaan besek Desa Tegaren untuk kemudian bisa tersalur ke kota-kota besar, termasuk Surabaya. Walaupun hanya memiliki frekuensi kegiatan satu tahun sekali, namun tim peneliti percaya bahwa kehadiran bantuan program ini akan memiliki dampak yang cukup signifikan terhadap Desa Tegaren, khususnya kepada para pengrajin besek. Program Besek Untuk Kurban pada akhirnya mampu memberi pendapatan tambahan kepada para pengrajin besek. Hal ini menegaskan bahwa dari besek, kehidupan di Tegaren telah terbangun dengan begitu kuatnya. Sehingga besek dan bambu ini merupakan roda ekonomi yang bisa digerakkan dari dalam maupun dari luar Tegaren. 


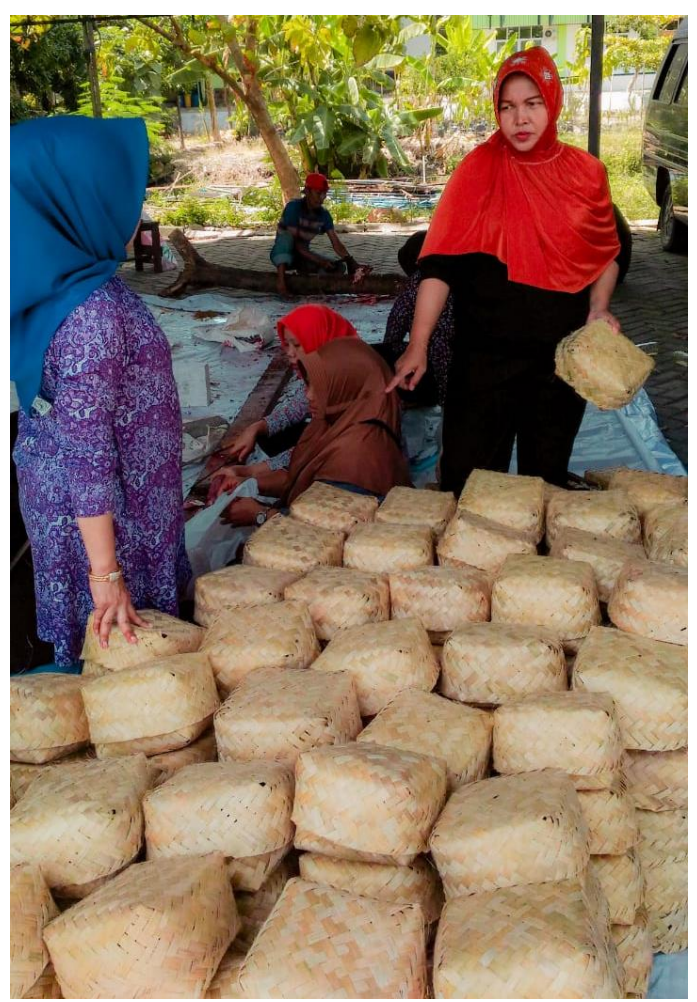

Gambar 4. Penyaluran besek dari Desa Tegaren di Masjid Istiqomah, UPN “Veteran” Jawa Timur untuk program Besek Untuk Kurban.

Sumber: Dokumentasi peneliti (2019)

\section{Bambu dan Besek sebagai Tegaren's Tourism Backbone}

Pada metode $\mathrm{ABCD}$, ada penggolongan aset yang bisa dikembangkan lagi demi meningkatkan kapasitas sebuah komunitas/entitas. Keenam aset tersebut adalah (1) aset sumber daya alam atau aset alam, (2) aset sumber daya manusia atau aset personal, (3) aset sosial; biasanya berbentuk asosiasi atau perkumpulan, (4) aset institusional, yang berbentuk organisasi legal formal, (5) aset fisik, (6) aset keuangan, dan (7) aset kultural/budaya (Dureau 2013). Aset-aset ini kemudian harus dimaksimalkan menurut pengalaman dan keinginan dari masyarakat lokal/setempat. Yang harus diperhatikan adalah bagaimana kemudian kita membedakan aset dan potensi. Dalam pemaknaan oleh Dureau (2013), aset adalah sumber energi sebuah komunitas yang sudah menjadi keseharian atau sistem kehidupan masyarakat tersebut. Sedangkan potensi lebih kepada hal-hal yang 
sebenarnya bisa menjadi aset, namun belum tersentuh oleh pengetahuan masyarakat.

Desa Tegaren sebenarnya memiliki potensi pertanian. Dengan kondisi geografis yang berbatasan langsung dengan Ponorogo, dan sebagaimana ciri khas daerah pinggiran, maka Desa Tegaren memiliki banyak lahan pertanian. Maka desa agraris ini memang banyak menghasilkan komoditas-komoditas pertanian. Namun, permasalahan pertanian di Tegaren juga tidak sedikit. Mulai dari kesuburan tanah yang semakin berkurang, berkurangnya bantuan penurunan harga bibit dan pupuk, sampai pada kepemilikan lahan yang masih belum bisa mengahasilkan pendapatan yang setara antara petani dan buruh tani. Tanaman coklat yang seringkali dimanfaatkan penduduk lokal justru terabaikan oleh masyarakat Tegaren. Kondisi air yang sangat minim di musim kemarau juga menjadi permasalahan. Mencari rumput untuk hewan ternak saja terkadang susah.

Tim peneliti sangat yakin bahwa bambu dan besek merupakan aset alam maupun aset kultural dari Desa Tegaren. Oleh karena itu, bambu dan besek adalah backbone kehidupan masyarakat desa yang tidak terlihat. Selain karena argumentasi bahwa hampir $100 \%$ penduduk wanita Tegaren adalah pengrajin besek, ada beberapa argumentasi lainnya. Bambu dan besek sudah menjadi kebudayaan bagi masyarakat Desa Tegaren. Kebudayaan dalam arti bahwa kemudian selain dijual, besek juga digunakan oleh penduduk lokal sebagai bagian kehidupan sehari-hari. Masih banyak penduduk yang menggunakan besek, dan kerajinan bambu lainnya, untuk peralatan masak. Begitu pula bambu sebagai bahan bangunan. Selain itu, besek juga sudah menjadi trademark sebagai bungkus oleh-oleh khas Trenggalek, yakni keripik tempe. Oleh karena itu, jika permintaan akan keripik tempe meningkat, maka permintaan akan besek juga meningkat pula. Selain keripik tempe, permintaan akan besek juga datang dari luar sebagai bungkus tahu kuning di Kediri dan tape singkong dari Bondowoso. Dengan ekosistem yang sangat mendukung ini, maka besek dan bambu layak menjadi backbone pengembangan desa wisata Tegaren. 
Dalam penentuan konsep Tegaren sebagai desa wisata, Embung Banyu Lumut hendak dijadikan atraksi pariwisata utama desa. Namun, karena lahan embung adalah lahan Perhutani, maka pengelolaan lahan masih dalam tahap pembicaraan lebih lanjut. Diambillah kerajinan besek sebagai atraksi pengganti Embung Banyu Lumut. Konsep yang awalnya adalah “destinasi wisata” kemudian ditetapkan sebagai "desa wisata”. Konsep desa ini selaras dengan tourist gaze 3.0 yang mengutamakan living experience dan ways of feeling. Maka, konsep desa wisata yang dibentuk di Tegaren akan mengutamakan pariwisata edukasi, seperti pariwisata membuat besek, pariwisata membuat batu bata, dan pariwisata bertani.

Konsep pariwisata membuat besek akan menjadi atraksi yang strategis sebagai konsep wisata yang dikembangkan di Tegaren. Ada tiga alasan mengapa pariwisata membuat besek akan menjadi atraksi wisata yang strategis. Pertama adalah karena kerajinan besek dikerjakan oleh penduduk perempuan di Desa Tegaren. Hal ini akan menjadi keunggulan tersendiri karena masyarakat perempuan rural masih memiliki fleksibilitas waktu yang tinggi. Sehingga pariwisata membuat besek akan menjadi atraksi yang bisa dinikmati kapan saja. Alasan kedua adalah kerajinan besek dikerjakan oleh hampir 100\% penduduk perempuan Tegaren, yang mana berarti atraksi wisata ini akan bisa dilaksanakan secara sporadis. Hal ini menjadi keunggulan tersendiri karena nantinya pariwisata tidak akan dilaksanakan hanya di satu tempat, namun bisa di tempat lain. Sehingga tidak begitu diperlukan jeda waktu yang lama. Alasan ketiga adalah pariwisata membuat besek termasuk wisata edukasi yang juga berarti segmentasi dari pariwisata ini bisa meluas mulai dari kalangan anak-anak sekolah sampai pada orang dewasa. Maka, selain menjadikan Desa Tegaren sebagai salah satu destinasi wisata edukasi, Desa Tegaren juga bisa menjadi rekan institusi pendidikan dalam konservasi budaya kerajinan besek. Hal ini menjadi keunggulan tersendiri karena secara pemasaran pariwisata kerajinan besek akan memperluas pemasaran yang ada. 


\section{Geoekonomi Besek Tegaren}

Istilah Geoekonomi sebenarnya digunakan oleh Edward Luttwak (dalam Dicken, 2011) untuk menggambarkan kondisi ekonomi global yang memiliki pola geografis tertentu. Hal ini senada dengan tesis capital shifting David Harvey (2005) yang menyatakan bahwa kapital (modal) akan beralih secara geografis ketika terdapat kejenuhan. Maka Harvey menunjuk fenomena seperti periode keemasan ekonomi Asia ketika sebelum Perjanjian Westphalia 1648 dan kejayaan benua Eropa setelah Perjanjian Westphalia 1648. Pada periode 2000-2050 diprediksi Asia akan menjadi pusat ekonomi dunia kembali, yang artinya bahwa sudah ada kejenuhan kapital di Eropa dan Amerika sehingga aktifitas ekonomi nantinya berpindah ke Asia. Senada dengan Luttwak dan Harvey, akademisi senior strategi pemasaran Michael H. Porter (1990) mengembangkan national's virtual diamond yang berisi strategi pemasaran negara dalam perekonomian global yang dipengaruhi oleh geografi nasional dan geografi pasar internasional. Maka, dari ketiga tesis tentang geoekonomi tersebut, konsep geoekonomi bisa kita tarik pada komoditas lokal dan untuk menganalisis perekonomian lokal.

Permintaan akan besek di Jawa Timur memang masih tinggi. Hal ini terbukti dengan meningkatnya harga besek yang dulunya Rp. 5.000,- per kodi sekarang menjadi Rp. 17.000,- sampai Rp. 20.000,- per kodi. Tegaren juga diuntungkan dengan posisinya yang terletak di kawasan perbukitan. Selain masih banyak menyimpan potensi lahan pertanian dan perkebunan, masih banyak lahan kehutanan yang bisa dikelola bersama oleh desa dan Perhutani. Kondisi perbukitan ini tidak hanya dimiliki oleh Tegaren. Beberapa desa tetangga juga terletak di daerah perbukitan, misalnya Desa Nglinggis, Desa Pucanganak, Desa Dermosari, dan Desa Jambu. Desa Winong sebagai desa yang berbatasan langsung dengan Tegaren juga memiliki lahan pertanian dan perkebunan yang sangat luas. Kegiatan studi banding kerajinan bambu yang dilakukan oleh tim peneliti dengan Pemerintah Desa Tegaren di Desa Wonoanti juga menyiratkan hal yang positif. Sentra Kerajinan Bambu Indah 
pimpinan Soekatno merupakan sentra kerajinan bambu terbesar di Trenggalek dan telah mencapai perdagangan ekspor.

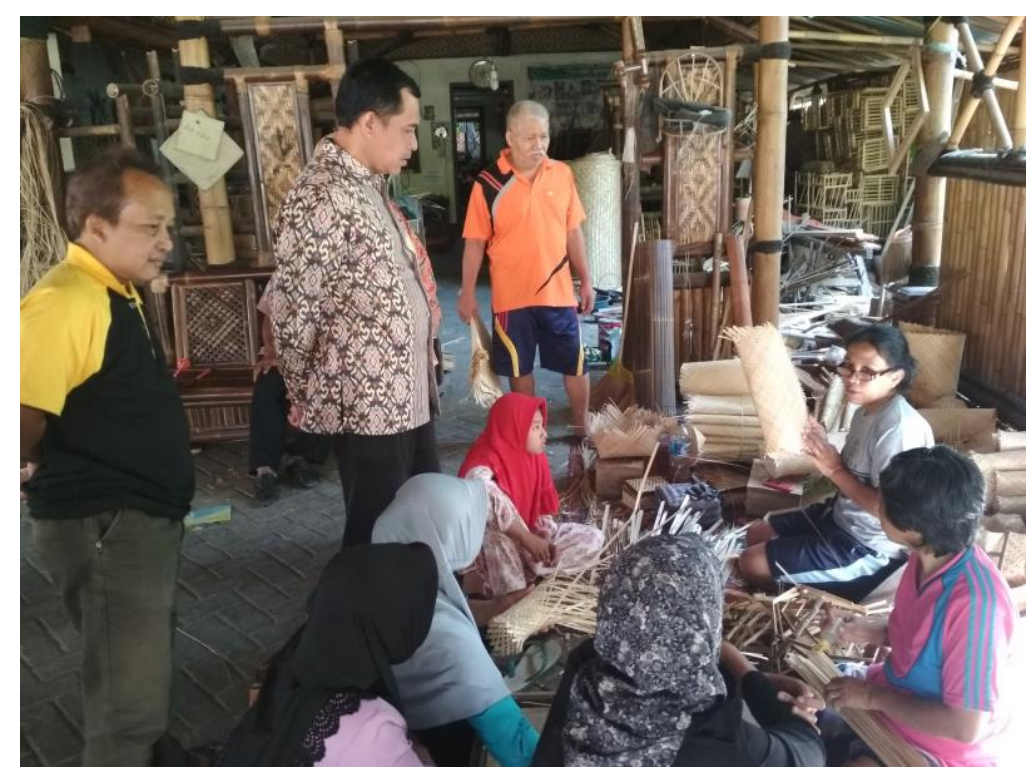

Gambar 5. Studi banding ke Sentra Kerajinan Bambu Indah di Desa Wonoanti, Trenggalek.

Sumber: Dokumentasi peneliti (2019)

Dari keterangan yang didapat tim peneliti, penawaran akan bambu tidak pernah habis. Bermacam-macam jenis bambu juga bisa didapatkan di Kabupaten Trenggalek. Hal inilah yang mendukung ekonomi bambu yang ada di Kabupaten Trenggalek secara umum. Selain itu, lokasi Kecamatan Tugu yang terletak relatif di Kabupaten Trenggalek bagian utara juga menguntungkan ekonomi bambu di Tegaren. Dengan ada di posisi utara, maka posisi Tegaren memang lebih dekat dengan Kediri dan Bondowoso, dua daerah dengan permintaan besek yang tinggi. Posisi di utara juga menguntungkan Tegaren karena sirkulasi aktifitas ekonomi (khususnya distribusi) juga banyak berkembang di bagian utara.

Sebagaimana telah disebutkan bahwa salah satu arti strategis Desa Tegaren adalah desa ini merupakan desa penyangga pariwisata Bendungan Nglinggis yang lokasinya berdekatan. Pada Bendungan Nglinggis, terdapat sentra produk atau kerajinan lokal, sehingga ketika Bendungan Nglinggis nanti telah rampung 
pembangunannya, diharapkan kerajinan atau produk-produk lokal dari Desa Tegaren dapat dipasarkan di Bendungan Nglinggis. Dengan lokasi yang berdekatan dengan Kabupaten Ponorogo, Bendungan Nglinggis memiliki arti strategis tersendiri bagi Desa Tegaren. Tentu saja Tegaren dan komoditas besek juga akan mendapat imbas positif jika destinasi wisata Bendungan Nglinggis berjalan sukses. Oleh karena itu, diharapkan dengan mengubah Desa Tegaren menjadi desa wisata dan menjadikan ekonomi bambu (besek) sebagai tulang punggung wisata desa akan membawa peningkatan taraf hidup masyarakat Tegaren secara keseluruhan dan dengan gradualitas yang tinggi.

\section{Kepemimpinan sebagai Faktor Penentu}

Telah dijelaskan bagaimana bambu dan besek sebagai aset alam dan aset budaya dalam metode $\mathrm{ABCD}$ dan komponen utama dalam pembangunan Desa Wisata Tegaren. Juga sudah dijelaskan bagaimana tourist gaze 3.0 berusaha dibangun di Desa Tegaren dengan konsep desa wisata sentra kerajinan besek. Namun, yang harus diingat adalah kepemimpinan sebagai faktor penentu dari efektif tidaknya dalam membangun bamboonomics (ekonomi bambu). Dalam sebuah karyanya untuk mengenang ilmu dari Peter Drucker, William Cohen (2013) bahkan menyebut kepemimpinan adalah definisi dari pemasaran itu sendiri. Dalam metode ABCD pun kepemimpinan juga menjadi salah satu komponen penting, yakni dengan konsep local champion. Local champion dalam konteks pembangunan desa wisata tidak terbatas hanya pada jabatan administratif, seperti Kepala Desa, ketua Kelompok Sadar Wisata (Pokdarwis), atau ketua Karang Taruna. Local champion juga bisa berarti orang yang punya pengaruh dan energi yang sangat besar sehingga bisa memberikan dampak kepada masyarakat. 
Pakar manajemen ternama, Rhenald Kasali (2015), menyebutkan bahwa kepemimpinan sejati merupakan sebuah rangkaian proses yang memiliki tujuan sangat panjang. Oleh karena itu, seringkali kepemimpinan yang baik tidak bisa selesai dengan satu periode pengurusan, tidak mungkin selesai dengan satu orang, dan tidak akan lebih baik ketika selesai hanya dengan program. Kepemimpinan yang visioner seperti ini disebutnya sebagai non-finito. Kepemimpinan non-finito sangat dibutuhkan oleh para local champion yang hendak membangun Desa Tegaren sebagai desa wisata. Desa wisata tidak bisa hanya dibangun melalui satu periode kepengurusan pejabat atau hanya dengan satu orang saja. Desa wisata harus dibangun berdasarkan pemikiran banyak orang dari berbagai generasi yang dilaksanakan dalam dua atau lebih periode kepengurusan.

Tim peneliti menemukan bahwa Desa Tegaren memiliki beberapa figur local champion yang visioner dan menjadi kunci dalam pembangunan desa wisata. Mulai dari Hendrik Krisdianto yang menjabat sebagai Sekretaris Desa, Gunawan yang menjabat sebagai Ketua Pokdarwis, dan Nurngaini sebagai pengrajin besek sekaligus pengepul besek dari masyarakat Desa Tegaren. Masing-masing dari local champion ini harus menyadari bahwa peran mereka sangatlah penting dalam menganyam ekonomi bambu yang ada di desa. Selama ini, peran Hendrik Krisdianto sebagai Sekretaris Desa bisa dibilang sangat melebihi ekspektasi. Sebagai Sekretaris Desa, Hendrik mampu menggerakkan perangkat desa beserta para pemuda desa baik yang ada di Karang Taruna maupun yang ada di Persaudaraan Setia Hati Terate (PSHT). Sedangkan Gunawan adalah petani biasa, namun semangat dan wawasannya yang luas selalu menjadikannya panutan pemuda-pemudi di desa. Sedangkan Nurngaini adalah pengepul dan pengrajin asli Tegaren yang aktif menggerakkan para pengrajin besek. Peran-peran krusial mereka nampaknya mampu membawa perubahan secara gradual pada Tegaren, terutama kaitannya dengan desa wisata. Terbukti dengan adanya kerja keras dari mereka, dan juga seluruh warga Tegaren, desa ini mampu mendapatkan Bantuan Keuangan Khusus 
(BKK) dari Kabupaten Trenggalek terkait pengembangan desa wisata pada tahun 2019. Sebuah bantuan selektif yang belum pernah diterima Desa Tegaren sebelumnya.

\section{Simpulan dan Saran}

Tegaren merupakan desa produsen besek terbesar di Kabupaten Trenggalek. Desa ini juga terletak di perbukitan, sehingga Tegaren masih memiliki suasana khas desa dengan udara yang sejuk. Desa Tegaren sendiri memiliki Embung Banyu Lumut, yakni danau buatan untuk menampung air, dan dalam konteks Desa Tegaren, mereka menggunakan Embung Banyu Lumut sebagai salah satu atraksi wisata. Oleh karena beberapa faktor pendukung tersebut, Desa Tegaren merupakan sebuah desa yang disiapkan untuk menjadi desa wisata, khususnya wisata edukasi pembuatan besek. Hal inilah yang kami sebut kemudian sebagai ekonomi bambu atau bamboonomic. Kombinasi antara konsep desa wisata dengan bamboonomic memunculkan harapan akan peningkatan kualitas kehidupan masyarakt Desa Tegaren.

Ekonomi bambu dipilih karena tiga fondasi analisis keilmuan. Ketiga fondasi tersebut yakni (1) bahwa ekonomi bambu adalah aset alam dan aset budaya yang sudah menjadi salah satu jantung kehidupan masyarakat Desa Tegaren, (2) bahwa ekonomi bambu yang digabungkan dengan desa wisata akan membuat Tegaren sebagai destinasi wisata yang mengandalkan ways of feeling dari konsep tourist gaze 3.0, serta (3) faktor kepemimpinan yang dimunculkan dan memunculkan ekonomi bambu sebagai denyut kehiudupan masyarakat Desa Tegaren. Ketiga fondasi tersebut merupakan hasil analisis tim peneliti dari studi lapangan yang telah dilakukan selama kurang lebih satu tahun. 
Satu hal yang perlu diingat adalah konsep desa wisata tidak akan pernah bisa berjalan ketika tidak ada partisipasi dari masyarakat di desa. Oleh sebabnya, partisipasi masyarakat di desa perlu dijaga agar tetap terus meningkat. Perlu dipikirkan akan perencanaan kegiatan-kegiatan yang mendukung berkembangnya desa wisata. Maka ada tiga saran untuk terus mendukung perkembangan desa wisata Tegaren, yakni 1) semakin banyak masyarakat yang berpartisipasi, semakin baik, 2) perlu adanya konsolidasi organisas-organisasi desa yang bersinggungan langsung maupun tak langsung dengan perkembangan desa wisata, dan 3) kegiatankegiatan yang berhubungan dengan desa wisata agar semakin ditambah.

\section{Ucapan Terima Kasih}

Ucapan terima kasih yang pertama dan paling utama kami haturkan kepada Tuhan Yang Maha Esa karena telah memberikan kelancaran dalam proses penelitian kami selama lebih dari satu tahun mengabdi di Desa Tegaren. Kami juga menghaturkan banyak terima kasih kepada rekan sejawat di Program Studi Hubungan Internasional UPN "Veteran" Jawa Timur yang selalu mendukung penelitian ini. Terakhir, adalah sebuah kehormatan dan berkah yang luar biasa bagi kami, selaku peneliti, untuk bisa belajar bersama-sama dengan masyarakat Desa Tegaren. Kami berterima kasih kepada seluruh perangkat desa Tegaren dan semua elemen masyarakat Desa Tegaren yang saling gotong-royong membantu tumbuh berkembangnya desa wisata Tegaren.

\section{Daftar Pustaka}

Agfianto, Tomi, Made Antara, dan I Wayan Suardana. 2019. “Dampak Ekonomi Pengembangan Community Based Tourism terhadap Masyarakat Lokal di Kabupaten Malang (Studi Kasus Destinasi Wisata Café Sawah Pujon Kidul)", dalam Jurnal Master Pariwisata (JUMPA), Vol. 5, No. 2, 2019. 
Center for Glocalisation Studies. 2018. Laporan Pra-Penelitian Desa Wisata Tegaren Oktober 2018. Dokumen Resmi Pusat Kajian Center for Glocalisation Studies (CGaS).

Conger, Jay. 1991. "Inspiring others: The language of leadership", dalam The Executive, 5 (1): 31-45.

Dicken, Peter. 2011. Global Shift: Mapping the Changing Countours of the World Economy. London: The Guilford Press.

Dureau, Christopher. 2013. Pembaru dan Kekuatan Lokal untuk Pembangunan. Australian Community Development and Civil Society Strengthening Scheme (ACCESS) Phase 2.

Ganz, Marshall. 2010. "Leading Change: Leadership, organization, and social movements", dalam Handbook of Leadership Theory and Practice. Boston: Harvard Business Press.

Goleman, Daniel. 1998. “What Makes a Leader?", dalam HBR's 10 Must Reads on Leadership. Harvard Business Review.

Harvey, David. 2005. A Brief History of Capitalism. Oxford: Oxford University Press.

Kasali, Rhenald. 2015. Change Leadership: Non-Finito. Mizan: Jakarta Selatan.

Kretzmann, Jody dan John McKnight. 1993. Building Communities from the Inside Out: A Parth Toward Finding and Mobilizing a Community's Assets. The Asset Based Community Development Institute, Institute for Policy Research. Illinois: Northwestern University.

Larsen, Jonas. 2014. "The Tourist Gaze 1.0, 2.0, and 3.0", dalam The Wiley Blackwell Companion to Tourism. John Wiley and Sons, Ltd.

Porter, Michael H. 1990. New Global Strategies for Competitive Advantage. Planning Review, 1990.

Russel, Cormac. 2016. Sustainable Community Development - from whats wron'g to what's strong. TED ${ }^{\mathrm{x}}$ Exeter. (daring). Tersedia di: https://www.youtube.com/watch?v=a5xR4QB1ADw. Diakses pada: 27 September 2018. 
Sudarmayasa, I Wayan, dan I Wayan Lanang Nala. 2019. “Dampak Keberadaan Sektor Pariwisata terhadap Peningkatan Faktor Sosial Ekonomi Masyarakat Kampung Tenun Samarinda di Kota Samarinda Kalimantan Timur", dalam Jurnal Master Pariwisata (JUMPA), Vol. 5, No. 2, 2019.

Universitas Pembangunan Nasional "Veteran" Jawa Timur. 2017. Kesepakatan Bersama Antara Pemerintah Kabupaten Trenggalek Dengan Universitas Pembangunan Nasional "Veteran" Jawa Timur Nomor SKB/31/UN63/2017 Tentang Pendidikan, Penelitian, dan Pengabdian Kepada Masyarakat. Dokumen Resmi UPN "Veteran" Jawa Timur.

Urry, John. 1990. The Tourist Gaze: Leisure and Travel in Contemporary Societies. London: Sage Publications.

\section{Profil Penulis}

Dr. Jojok Dwiridhotjahjono, M.Si adalah dosen Ilmu Administrasi Bisnis UPN "Veteran" Jawa Timur. Beliau menyelesaikan Program Sarjana Ilmu Administrasi di Universitas Jember, Program Magister dan Doktoral Ilmu Administrasi di Universitas Brawijaya Malang. Email: jojokdwiri@gmai.com

Prihandono Wibowo, M.Hub.Int adalah dosen Program Studi Hubungan Internasional UPN “Veteran" Jawa Timur. Ia menempuh Program Sarjana dan Magister Hubungan Internasional di Universitas Airlangga Surabaya. Email: prihandono wibowo@yahoo.com

Praja Firdaus Nuryananda, M.Hub.Int adalah Kepala Laboratorium Program Studi Hubungan Internasional UPN “Veteran" Jawa Timur sekaligus anggota Dewan Pendidikan Kota Kediri, Jawa Timur, 2016-2021. Ia menyelesaikan Program Sarjana dan Magister Hubungan Internasional di Universitas Airlangga Surabaya. Email: firdaus.praja@gmail.com 